\title{
Waqf Endowments in the Old City of Jerusalem: Changing Status and Archival Sources
}

\author{
Salim Tamari
}

The Old City of Jerusalem is unique in its predominance of endowed, or waqf, properties (public and family-based). At the end of the twentieth century, waqf properties in all categories totaled 1,781 units, or 54 percent of all properties in the Old City. ${ }^{1}$ In terms of area, these properties amounted to 348 dunams ( 1 dunam $=0.247$ acres), or about 66 percent of the total area of the Old City. One quarter of those were family endowments (waqf dhirrì), equivalent to 567 units or 84 dunams. The revenue of these endowments was assigned to both private and charitable purposes, which will be explained below. The task of finding accurate sources for interpreting the scope and character of these properties has been a major challenge for the historian. Court records and land registry archives have been plagued with problems of accessibility, shifting registration procedures, and proper bureaucratic organization of registered properties. An additional problem was the layers of leasing and subleasing of waqf properties, some of which were never registered. Since 1967 , another problem has emerged: the abuse of archaic legal categories of endowments by the State of Israel and its propensity to sequester waqf property on behalf of the state and settler groups. In this chapter I will examine how new archival sources can help to shed light on the extent and nature of these family and public endowments. These archival sources include municipal tax registries for Old City properties, aerial photography and on-site architectural surveys.

Several historical sources have examined the evolution and changing uses of these endowments, which will be cited in this review. Of immediate relevance to our study is a survey undertaken by the Arab Studies Society and the Welfare Association in the last two decades, from which the statistical material for this analysis is derived. ${ }^{2}$ Of the historical sources, two of the most cited

1 "The area under examination" in the original survey refers to the Muslim, Christian and Armenian quarters. The expanded Jewish quarter (after 1967) will feature in a separate volume of the survey, due to be published in 2018. In this essay I examine Jewish properties and endowments and compare them with the material for the three other neighborhoods.

2 See previous footnote.

(C) SALIM TAMARI, 2018 | DOI:10.1163/9789004375741_031

This is an open access chapter distributed under the terms of the prevailing CC-BY-NC-ND License at the time of publication. 
are Mujir al Din's classic study al-Uns al-jalil bi-tarikh al-Quds wa-l-Khalil ${ }^{3}$ and Muhammad Ghushah's more recent study of Islamic waqf and its history. ${ }^{4}$ The significance of these sources lies in their documentation of the changes in the size and status of these properties during the Ayyubid, Mamluk, and Ottoman periods. Most of the historical sources suffer from two major pitfalls: they do not examine the fate of waqf properties after the end of the Ottoman era (1917). They mainly address the conditions of Islamic family and public waqf, but not those of non-Islamic institutions and owners. This gap is especially problematic since Rum Orthodox and Armenian Church endowments alone control 131 dunums, or 25 percent of the area under study. A few historical works have addressed this lacuna in the late Ottoman period, including 'Abd al-Aziz Madani's Islamic Waqf in Jerusalem and its Environment ${ }^{5}$ and Ahmad Hamid Ibrahim al-Quda's The Christian Presence in Jerusalem in Ottoman Documents. ${ }^{6}$

This chapter addresses the status of waqf properties in Jerusalem during the second half of the twentieth century. It makes use of spatial field surveys and GIS technologies and draws on several available archival sources including aerial surveys and municipal tax records. The available data still contains a number of gaps and inconsistencies resulting from the historical shifts in regulations governing endowed properties and from multiple leases and subleases of these properties. We have pointed to the limits and pitfalls in our assessments of the size and nature of these loopholes, but hope that the new data utilized here may rectify earlier shortcomings. ${ }^{7}$

3 'Abd al-Rahman ibn Muhammad al-'Ulaymi, Al-Uns al-jalil bi-tarikh al-Quds wa-l-Khalil [The glorious history of Jerusalem and Hebron] (Najaf: al-Mațba'ah al-Ḥagdarīyah, 1968). For a contemporary analysis, see Donald P. Little, "Mujīr al-Dīn al-'Ulaymī's Vision of Jerusalem in the Ninth/Fifteenth Century," Journal of the American Oriental Society 115, no. 2 (1995).

4 Muhammad Hashim Musa Dawud Ghushah, Al-Awqāf al-Islamiyya fi-l-Quds al-sharif: dirasa tarikhiyya muwathaqa [Islamic waqf in Jerusalem: a historical documentation] (Istanbul: IRCICA, 2009).

5 Ziyad 'Abd al-Aziz Madani, al-Awqaf fi al-Quds wa-Jiwariha khilal al-qarn al-tasi' 'ashr al-miladi, 1215 H/180oAD-1336H/1918AD [History of awqāf in Jerusalem and its environs, 18001918] (Amman: al-Madan̄̄, 2004); see also Ziyad 'Abd al-'Aziz Madani, al-Awqaf al Masihiyyag fi-l Quds wa jiwaraha fil Qarnain al Thamin ashar, wal tasi' ashar al miladiyyin, 1700-1918 [Christian endowments in Jerusalem and its environs, 1700-1918] (n.p., 2010).

6 Ahmad Ḥamid Ibrahim Quḍa, Nasarả al-Quds: dirasa fi daw'al-wathảiq al-'uthmaniyya [The Christians of Jerusalem in light of Ottoman documents] (Beirut: Markaz Dirāsāt al-Waḥdah al-Arabīyah, 2007).

7 For a discussion of these limitations, see the monograph from which this essay is extracted: Munir Fakhr ed-Din and Salim Tamari, [Jerusalem properties and endowments in the 2oth century] (Beirut: Institute for Palestine Studies, forthcoming 2018, in Arabic). 


\section{Charitable and Family Waqf}

The primary distinction in endowed properties in Palestine is between those estates allocated for general charitable uses (waqf khayrī) and those confined for family use (waqf dhirrī) in perpetuity. Another distinction differentiates between what is known as "proper" waqf (waqf sahịh), pertaining to privatelyowned land, and "improper" waqf, pertaining to what was originally royal or sultanic land (amiriyya land) which had been allocated for the benefit of persons or charitable institutions but was retained in the control of the state or of the state treasury (beytülma $\bar{l})$. ${ }^{8}$ I will examine below the ramification of this distinction for Jerusalem's waqf properties when I discuss the extensive holdings of Hasseki Sultan endowments.

Insofar as the first distinction is concerned, there is an overlap between dhirri and charitable waqf, but only in one direction. Family waqf can acquire charitable functions in several cases, but most commonly when the revenue from a family property is allocated for the benefit of the needy from among kin members and outside the family. It may also be transferred entirely outside of family use and used for general welfare; this is the case when the lineage of the endowing family is terminated. ${ }^{9}$

The most common uses of both khayri and family waqf in Jerusalem are known as tảjir and tahkìr (short- and long-term leasing). The long-term leases are a source of continued conflict. Both cases confer leaseholds for a period not exceeding three years. It was assumed in the law that the mutawalli (supervisor) of the waqf would terminate the contract at the end of the three years in order to preserve the legal status of endowed property. Nevertheless, this principle was constantly violated in practice, especially in the case of hikr agreements. Hikr (literally "monopoly") is a long-term lease which allows the lease tenant, with the permission of the mutawalli, to build new constructions on the surface of endowed properties. It also allows the leasee (al-muhtakir) to sell, lease, or place under a new endowment the newly-constructed property without undermining or altering the status of the original endowed property. ${ }^{10}$ There are several negative consequences of hikr leases for the property holder. The most common of these consequences is the deterioration in the value of the rent over time due to inflation. Other consequences are the

Riyad Shahin and Ibrahim Ni'matallah, Al-Mulkiyyat wal Darảib fi al Ramlah fi Sijjilat al-Mahakim al-Shariiyya 1864-1914 [Land ownership and taxation in Ramla from Islamic court sijillāt, 1864-1914] (Gaza: Gaza Islamic University, 2005).

9 Ibid., 8.

$10 \quad$ Ibid., 9-10. 
erosion of the legal owner's ability to maintain their rights during a regime change, and loss of the original ownership documentation. Shahin refers to the case of hikr properties belonging to the Radwan family in Ramla, similar to many cases in Jerusalem's Old City, in which the total annual waqf revenue amounted to merely ten piasters after decades of tenant occupancy. ${ }^{11}$

\section{Waqf in Historical Perspective}

The earliest documentation of waqf properties in Jerusalem date to the Ayyubid period, following the liberation of the city from Frankish rule. Sultan Saladin and subsequent governors began to consolidate the Islamic charitable institutions through the establishment of a network of schools, soup kitchens (takaya), and hospices to serve the city's population. Those investments were resumed after a long disruption, following the end of the Third Crusade, during Mameluke rule. The most important endowments then were those established by Sultan Dhaher Baybars (AD 1269), Emir Tankiz (1329), and the endowments of Prince Manjak (1355), and exist in extant archival sources of tax records and court sijillät. ${ }^{12}$ A more rigorous record of later endowments began in the Ottoman era during the sixteenth century. Those are documented in court sijillāt and in $\underline{H} \bar{a} k \hat{a} \bar{a} n \bar{\imath}$ records (known as Tapu tahrīr defterleri)..$^{13}$

Probate courts continued to register family waqf properties in Jerusalem after the sixteenth century, but a comprehensive survey of these estates is difficult due to the disorganized and dispersed character of these records. Major endowments belonging to the major potentates, including to the 'ayan of Jerusalem, such as the al-Khatib, Danaf, Ansari, Husayni, Khalidi, Budeiri, Imam, Quayder, Turjman, Nashashibi, and Quttaineh families, are well-documented. ${ }^{14}$ These wealthy family estates make up a substantial proportion of all family endowments in the city of Jerusalem.

\footnotetext{
11 Ibid., 11-12.

12 Muhammad Ghusha, "Al-Mulkiyyat al-Waqfiyya al-Maqqdisiyyah fil-Qarn Sadis-'ashr min khilal al-sijillat al "Uthmanioyyah" [Jerusalem waqf properties in the 16th century in Ottoman sijjils, dafters, manuscripts], in Awraq 'A'iliyya: Dirasat fi Tarikh Filastin al mu'asir [Family papers: studies in contemporary social history], ed. Muhammad Zakariyya et al., 2nd ed. (Ramallah: Institute for Palestine Studies, 2011), 241.

13 Ibid., 243-44. See also "List of Published Ottoman Tax Registers (Tahrir Defterleri)," Economic History of the Ottoman Empire website, n.d., accessed January 19, 2018, http:// ottoman.uconn.edu/bibliography/published-tahrirs/.

14 The list of these endowments and their size appear in table G-3, in Fakhr ed-Din and Tamari, Jerusalem Properties.
} 
Dhirrī endowments are not exclusive to Muslim families - Jewish and Christian family properties also possess them. The combined Christian public and private endowments constitute a very substantial proportion of all endowments in the city. Ziad al-Madani has estimated the number of Christian family waqf to constitute 48 percent of all dhirri waqf contracts for Jerusalem during the early twentieth century. Public endowments were bigger in size due to the nature of church and monastic estates in the city.

Abdul Karim Rafiq has examined the changing character of dhirri endowments in Palestine in his analysis of the Dabbas family waqf recorded in the Jaffa sharica court records on April 4, 1859. ${ }^{15}$ The endowment consists of urban real estate, agricultural landed property, and transferable assets in the cities of Jaffa, Ramla, Lydda, and Jerusalem. Rafiq argues that even though this endowment was registered by a Christian Orthodox family from Jaffa, the conditions of Islamic dhirri waqf apply. The conditions are the registration of endowed estates, the stipulation of the beneficiaries of its revenue, and the determination of its future disposition in the case of the death or demise of the original beneficiaries.

This endowment has all the main attributes of major family endowments. For example, it contains mansions, residential apartments, and orange groves (bayyarat) in the vicinity of Jaffa and Lydda as well as in Jerusalem. It also includes soap factories, vineyards, and courtyards (ahwāsh). The endowment also covers transferable assets such as olive oil jars and qantars (a measure of weight) of soap and rice. It also contains monetary assets such as gold and silver. The waqf contract lists the categories of beneficiaries from the dhirri endowment after deductions are made for the nazir of the waqf in the form of a salary for this position. The nazir in this case is the mutawalli of the endowment - normally chosen from among the mature male adult children of the waqif (endower), for rarely is the nazir a female or an outsider to the family. If the nazir fails to fulfill the conditions of his tenure, he may be removed from office. ${ }^{16}$ The usual beneficiaries of the waqf are the sons and daughters of the endower for several stated numbers of generations (usually three or four), after which it continues with the male line only. This changed condition is meant to block the transfer of the waqf revenue to the benefit of "outsiders" (aghrab, lit. "strangers"). A portion of the revenue is often allocated for the poor within the religious community of the donor. In this last case, family waqf and general (khayrī) waqf become identical.

\footnotetext{
15 Abdul Karim Rafiq, "The Dabbas Waqfiyyah at the Jaffa Court, 1 Ramadan 1275/April 4, 1859 and its Spatial, Economic and Social Attributes," Kronos 30 (2014): 77.

16 Rafiq, "The Dabbas," 78.
} 
Rafiq notes that endowed properties used to be leased for a period not exceeding three years, as stipulated by the dominant Hanafi legal school during the Ottoman period. Yet this stipulation was often violated, and increasingly so during the British Mandate period. ${ }^{17}$ An important difference between Islamic and Christian dhirri endowments is that Muslim contracts usually do not stipulate that the beneficiaries of the endowments must remain within the religious sect of the original endower, whereas this is common in Christian contracts. This difference is due to the rarity of religious conversion in Muslim cases. ${ }^{18}$

\section{Particularities of the Jerusalem Waqf}

Philanthropic waqf (khayrī) properties in Jerusalem are distinguished by their proportionally large size and numbers compared to similar endowments in the rest of the Middle East. Yitzhak Reiter, a leading authority on religious endowments, notes that the number of waqf properties in Jerusalem has surpassed on a per capita basis those of Istanbul, Cairo, Aleppo, and Bursa. ${ }^{19}$ Initially this was due to the religious importance of Jerusalem, through which many successive Sultans and princes in the Ayyubid, Mamluk, and Ottoman periods assigned local endowments for the service of pilgrims and the urban poor. In most cases they established waqf institutions to immortalize their or their wives' names. Celebrated examples of such cases are the Hasseki Sultan waqf, established by Princess Roxelana, and the Abu Madyan waqf in the Mughrabi Quarter, established by Abu Madyan al-Ghawth in AD 1320 to serve as residencies for pilgrims from the Maghreb in the vicinity of al-Buraq. These residencies later evolved into the Old City's Moroccan Quarter. ${ }^{20}$

During the Ottoman period, khayri waqf institutions proliferated in the form of schools, religious seminaries (zawāya), and Sufi soup kitchens (takaya). Muhammad Dawud Tamimi estimates that public waqf institutions belonging to Sufi groups constituted 46 percent of all endowed properties

17 According to sharica principles, endowed leases are normally contracted for one year in real estate, and for three years in agricultural properties. See Rafiq, "The Dabbas," 79.

18 Ibid., 81.

19 Yitzhak Reiter, Islamic Institutions in Jerusalem: Palestinian Muslim Organization under Jordanian and Israeli Rule (The Hague: Kluwer Law International, 1997), 26-27.

20 Ghusha, "Al-Mulkiyyat al-Waqfiyya" [Jerusalem waqf properties], 244. 
during the sixteenth century. ${ }^{21}$ According to Reiter, Jerusalem had the lion's share of all waqf properties in Palestine, noting that khayri waqf registered in sharica courts for Jerusalem amounted to 86 units, compared to 144 units registered in all other cities and villages, during the Ayyubid, Mamluk, and early Ottoman eras. ${ }^{22} \mathrm{He}$ notes the enhanced role of both khayri and private (family) waqf during the late Ottoman period, as well as during the British Mandate. Another surge in family waqf occurred during the period of Israeli occupation after $1967 .{ }^{23}$ During the British Mandate, the Higher Islamic Council purchased considerable landed properties and real estate in Palestine and converted them to public endowments in order to preempt the purchase of these lands by Zionist groups. These areas included several properties surrounding the Haram al-Sharif area and in the Mount of Olives (al-Tur), Baq'a and Talbieh neighborhoods. ${ }^{24}$

After a short hiatus during the Jordanian period, the process of endowment registration resumed its pace after the Israeli occupation of the city in 1967 . Ninety waqf properties were registered (one-third of which were charitable endowments) between 1967 and 1990 alone - compared with only 16 endowments registered during the Jordanian administration. More significant was the sudden rise in the number and size of family endowments during the same period. The total registered waqf properties in the Jerusalem and Jaffa courts (for Jerusalem registrations) amounted to 90 units between 1967 and 1993. Of those, 24 were khayri waqf and 66 were dhirrì waqf. In contrast, only 16 dhirri waqf contracts were recorded during the Jordanian from 1948 to $1967 .{ }^{25}$

The period after 1967 witnessed increased preoccupation with waqf properties as an instrument to enhance the sustenance and survival of Arab institutions in Jerusalem. Several institutional and state donors gave financial aid to Jerusalem institutions and required that their aid be conditioned on converting the assets of the receiving institutions into trust funds (mu'assasāt mawqüfa). ${ }^{26}$ This process was extended to a number of charity establishments that were originally established as public bodies or Ottoman societies

21 Muhammad Dảud al-Tamimi, Awqaf wa Amlak al Muslimin fi Filastin [Muslim waqf properties in Palestine] (Istanbul: Organization of Muslim Congress, 1984).

22 Reiter, Islamic Institutions, 26.

23 Ibid.

24 Ibid., 27.

25 Ibid., 29-34.

26 Michael Dumper, Islam and Israel: Muslim Religious Endowments and the Jewish State (Washington, DC: Institute for Palestine Studies, 1994), 183-230. 
according to civil law, and were then converted into waqf establishments registered in shari'a courts. Examples of these waqf institutions are the Arab Women's Union, headed by the Jerusalemite woman leader Zulaykha al-Shihabi and the Ibrahimiyyeh College. ${ }^{27}$ This meant that the disposition of their assets and properties were now governed by the sharia courts, which blocked their transfer to other private bodies in case of bankruptcy or self-dissolution.

There is no doubt that the conversion of private properties into the status of dhirri waqf and of public institutions into khayri waqf institutions has protected these properties from fragmentation and - in many cases - from confiscation by the state. Dhirri waqf was an answer to the fragmentation of private property through inheritance. Similarly, the conversion of public institutions to khayri waqf has preempted the possibility of their sequestration or sale through privatization. Nevertheless, over the past five decades, the measures of protection taken have not always succeeded in preventing endowed land and properties from being subject to Israeli measures of control (see table 25.1). Israeli measures included:

a. The confiscation of waqf lands by declaring the territory in question as a security zone for military use.

b. Declaring the land or real estate as abandoned property (matrūka) if the mutawalli or caretaker of the property is an absentee, under Israeli law.

c. Declaring the endowed property to be state land (miri $\bar{l})$, and thus as "improper" waqf (waqf ghayr sahịh). These measures have often been applied to substantial agricultural land which were formerly registered as mīrī waqf. ${ }^{28}$

The Israeli government has also attempted, though not always successfully, to prevent the increase of endowed properties by legal and administrate measures such as:

27 Reiter, Islamic Institutions, 36-37.

28 Dumper, Islam and Israel, 157-59. Dumper notes that "while endowed estates established on private property (that is, "true or proper waqf") were not affected, nevertheless much of lands in the West Bank, including Jerusalem area waqf that were declared as miri land, and whose status were previously registered as waqf, were confiscated by military decisions. Those areas affected included lands administered by the Islamic Higher Committee, such as the al-waqf al-Khalili lands." Khalili waqf refers to public Islamic endowments in Palestine attributed to the patrimony of the prophet Ibrahim, also known as al Khalil (i.e. "the friend of God"). 
d. Undermining the legal status of decisions by the waqf administration and Jerusalem probate courts. First by coopting the waqf administration at the beginning of Israeli rule and then by challenging the domain of the Islamic Higher Committee, which came to administer these properties. The government also refused to acknowledge the decisions of the appeals court, and deported a number of judges and clerks of the Islamic Committee in the late 1960s and 1970s.

e. Attempting to transfer all decisions pertaining to waqf properties to the Islamic waqf administration in Israel and to the Jaffa shari'a court. Both of these institutions were more controllable by the Israeli state. These measures have been partially successful, since most family endowments are today subject to the appointments of their managers (mutawallis) by the Jaffa courts.

f. The Israeli state benefitted from the disputes between the Palestinian Authority and the Jordanian waqf administration in the West Bank and Jerusalem. The state was able to nullify many of the Palestinian Authority's decisions about waqf appointments and regarding revenues. ${ }^{29}$

The forgoing discussion about the preponderance of endowed properties in Jerusalem applies even more sharply to the situation in the Old City, which measures about one square kilometer. The sacred space of Old Jerusalem has been the main recipient of philanthropic endowments by governors, city notables, and religious institutions over the centuries. These endowments were aimed at giving legitimacy to dynastic rulers, new regimes in power, or for the benefit of followers of particular religious communities, sects, or Sufi orders. Endowments were often used to immortalize the name of the benefactor(s) and to secure a safe place for them in the afterlife. Christian orders have been particularly keen to provide endowments as sources for residential dwellings for their denominations. This explains to some extent the relatively large waqfiyyāt belonging to certain churches in the Old City, which is examined in table $25 \cdot 1 .^{30}$

29 Dumper, Islam and Israel, 15.

30 It is important to highlight that the dependence on aerial photography in calculating the parameters and coordinates of these endowed properties can lead to a certain degree of error. For details on these discrepancies, see "Methodological Note" in the introduction to the original study, Fakhr ed-Din and Tamari, Jerusalem Properties. 
TABLE 25.1 Distribution of plots and percentage: total area and percentage, according to kind of property, 1967

\begin{tabular}{|c|c|c|c|c|c|c|}
\hline $\begin{array}{l}\text { Category } \\
\text { of property }\end{array}$ & $\begin{array}{l}\text { Number } \\
\text { of plots }\end{array}$ & $\begin{array}{l}\text { Percentage } \\
\text { of plots }\end{array}$ & $\begin{array}{l}\text { Total area } \\
\text { in dunums } \\
\text { (excl. } \\
\text { Haram } \\
\text { and Jewish } \\
\text { Quarter) }\end{array}$ & $\begin{array}{l}\text { Percentage } \\
\text { of area in } \\
\text { dunums } \\
\text { (excl. } \\
\text { Haram } \\
\text { and Jewish } \\
\text { Quarter) }\end{array}$ & $\begin{array}{l}\text { Total area } \\
\text { in dunums } \\
\text { including } \\
\text { Islamic } \\
\text { waqf, but } \\
\text { excluding } \\
\text { expanded } \\
\text { Jewish } \\
\text { Quarter }\end{array}$ & $\begin{array}{l}\text { Percentage } \\
\text { thereof }\end{array}$ \\
\hline State property & 11 & 0.3 & 21 & 4 & 21 & 3 \\
\hline $\begin{array}{l}\text { Jerusalem } \\
\text { municipality }\end{array}$ & 27 & 1.0 & 2 & 0.3 & 2 & 0.2 \\
\hline $\begin{array}{l}\text { (Jordanian) } \\
\text { Custodian } \\
\text { of Enemy }\end{array}$ & 69 & 2.0 & 10 & 2.0 & 10 & 1.5 \\
\hline Property & & & & & & \\
\hline Islamic waqf & 302 & 9.0 & 36 & 7.0 & 180 & 27 \\
\hline Family waqf & $5^{67}$ & 17 & 84 & 16 & 84 & 12.5 \\
\hline Church waqf & 912 & 28 & 228 & 43 & 228 & 34 \\
\hline $\begin{array}{l}\text { Private } \\
\text { property }\end{array}$ & 1,404 & 43 & 145 & 28 & 145 & 21 \\
\hline Total & 3,292 & 100 & $5^{26}$ & 100 & 670 & 100 \\
\hline
\end{tabular}

SOURCE: RECORDS OF LAND AND PROPERTY ASSESSMENT FOR MUNICIPAL TAXES (TAKHMINAT), 1966 (INSTITUTE FOR PALESTINE STUdiEs ARCHIVES, BEIRUT).

\section{Family Endowments and Private Property}

Private land and real estate properties constitute slightly over one quarter (28 percent) of the total area of taxed property in the area under study. ${ }^{31}$ As noted earlier, the proportion of private ownership of land in Jerusalem is considerably lower than that of other historical cities in Greater Syria and inside

31 The area excludes the enlarged Jewish Quarter, which will be analyzed below, and the Haram al-Sharif area. 
Palestine. Total endowed (waqfiyyāt) properties make up an astonishing 66 percent of all surface area of the Old City, certainly much higher than other comparable urban area in the entire Middle East. Family waqf occupies 16 percent of the area under study, amounting to more than half of the area designated as "private domain." As for type of usage, we note that half of all family waqf endowments are used for residencies (48 percent). ${ }^{32}$ These residencies are mainly leased properties to dwellers who are not members of the endowing family. As for other uses, we note that $5^{6}$ percent of the units are leased for commercial use, making up 11 percent of the area of family endowments. ${ }^{33}$

There is little difference observed in the use of private properties in comparison with family endowments. About half of all private properties (47 percent) in the Old City have been used for commercial reasons while slightly less than half (49 percent) are designated as private residencies. However, the areas concerned differ in this case. The area used for commercial reasons in private ownerships is 10 percent of the total area in this category, while residencies occupy 83 percent. This means that most commercial establishments are made up of small shops. ${ }^{34}$ Calculations based on the size of all properties in the Old City show that 95 percent of land in commercial use fall into units of less than 100 square meters, of which 37 percent are designated as private property, 13 percent as Islamic waqf, 18 percent as family waqf, and 30 percent as church waqf. ${ }^{35}$

The distinction between the so-called "proper waqf" and "improper waqf" (waqf sahị and waqf ghayr sahịh) has been the source of major debates in legal circles, mainly because of the consequences emanating from these designations. Proper waqf (also known as "true" waqf) refers to lands and properties that used to be privately owned and which were designated by the owners as endowed for public charity or for the communal use of the family. Improper waqf (sometimes referred to as "untrue" waqf) refers to mìrì or royal lands, which the sovereign or the state has designated for private or charitable uses. Those designations include the establishments of princely feudal estates (iqta iyyat amiriyya) during the Ottoman period and probably in earlier Islamic periods. These distinctions do not appear in the records of endowments for Jerusalem, and we assume, therefore, that improper waqf designations are the exception to the rule. ${ }^{36}$

32 Fakhr ed-Din and Tamari, Jerusalem Properties, table D-3.

33 Ibid.

34 Ibid.

35 Ibid., table D-4.

36 Hasseki Sultan is a possible exception, which is discussed in the following section. 
More recently, a legal debate has emerged about the nature of Hasseki Sultan endowments in Jerusalem and other cities in the region (Izmir, Ramla, Jaffa and Medina), which were established by Roxelana, the wife of Sultan Süleiman. These endowments include schools, public baths, and soup kitchens (takaya) in the Old City of Jerusalem and other establishments in its vicinity. In his analysis of Hasseki Sultan endowments, Iskandar Salameh notes:

Improper waqf lands in Palestine include the Jiftlik [agricultural] lands which were ceded originally from state lands (arädi amiriryya) by the Sultan as [feudal] awards to public servants and military commanders. Some rulers set aside some of these properties to themselves as Sultanic areas - such as the properties known as Khaseki Sultan, and the Jiftlik land which was registered in the name of Sultan Abdülhamid II. ${ }^{37}$

Salameh then concludes that

the claim that Hasseki Sultan is proper ("true") waqf is based on a mistaken assumption and is aimed at securing an equal exchange of value (hikr property) from the owners of these endowed properties, in a manner that will render them as tenants, and subsequently to impose the authority of the waqf administration on the properties so that they can claim the value of the hikr from previous years. ${ }^{38}$

This assessment of Hasseki Sultan (and other so-called improper endowments) seems to apply to commercial endowments in Bethlehem, where the ownership claims are in dispute, and not on Hasseki Sultan takaya and schools in the Old City of Jerusalem, where the commercial use of the endowments have disappeared from living memory.

37 Iskandar Salameh, "Khaski Sultan, Lamha Tarikhiyya" [Hasseki Sultan Waqf: a historical note], Law Practice. Adv. Iskandar Salameh, June 3, 2012, accessed January 19, 2018, http:// lawpractice-iskandar.blogspot.com/2012/06/blog-post_03.html.

38 The Hasseki Sultan Waqf was established on Shawwal AH 964 (AD 1556). It states in its preamble: "What Princess Khaseki has endowed is registered as a proper and legal waqf, with clear and concise attribution" (Salameh, "Historical Note"). The expression "proper waqf" (waqf sahịh) in this document means that it was established by law, and not by decree. It differs, however, from the juridical terms of "proper waqf," which necessitates that the endowment cannot be Amiri (royal) estates, and that it cannot be established by order of the sovereign or ruler. 


\section{Public (khayrī) Endowments and the Custodian of Enemy Property}

Public (khayrī) endowments account for 264 dunums in the area under study, which is around 50 percent of the area examined above (see table 25.1). We should note that tax records do not include the Haram area, which amounts to an additional 144 dunums. If we add the Haram area to the Islamic public endowments, then the total khayri waqf would constitute more than a quarter of the examined area (27 percent). Without the Haram area, total Islamic charitable public waqf would amount to 7 percent from the land parcels in the Old City. Still Christian ecclesiastical waqf constitutes the majority of public endowments in Jerusalem's Old City. It amounts to 228 dunums or 43 percent of the total area under study (excluding the Haram area). In all the following statistical analysis these exclusions are assumed, except when the Haram area and the expanded Jewish Quarter are included in the data.

In terms of land use, there is considerable similarity between Christian and Islamic public awqāf - since the two main uses, commercial and residential, exhibit close patterns of usage. Commercial uses of endowed properties constitute 76 percent of Islamic waqf, and 62 percent of Christian waqf. In terms of residential uses, 10 percent of Islamic waqf and 30 percent of Christian waqf are residencies. In terms of area, the proportions are reversed (40 percent of Islamic waqf and 38 percent of Christian waqf are taken by residential units). These patterns clearly show that Christian churches invest a higher amount of their endowments in securing residencies in the Old City for their poor adherents.

The primacy of residential and commercial functions is followed by other uses such as religious worship facilities, public service facilities such as medical units and soup kitchens, and education. It is important to mention that the area and number of endowments allocated to education is very small in relative terms - only 11 percent of Islamic waqf and 4.7 percent of Christian waqf are allocated for education. One explanation for this seeming negligence is that many educational institutions in Jerusalem are registered outside the domain of public religious endowments. Another outstanding feature of Christian religious endowments is the absolute dominance of two churches in the size and number of their estates: the Rum Orthodox and the Armenians. ${ }^{39}$

Projections from this survey of waqf properties have excluded three main areas of considerable importance: the area around al-Haram al-Sharif, the blocks inside the Jewish Quarter which, since the occupation of Jerusalem in 1967, has been expanded in three directions, and the Mughrabi Quarter. The 
attributes of the Haram area are known in terms of size and its uses are known, but are not included in the calculations of this study. The expanded Jewish Quarter and the Mughrabi Quarter (which the Israeli government merged in 1967) make up blocks 29-38. These blocks house dispersed Jewish properties that came under the administration of the (Jordanian) Custodian of Enemy Property after the war of 1948. Until data about these blocks becomes more readily available, we must rely on the analysis provided by Adnan Abdul Raziq in a recent study. The data in table 25.2 is derived from this study, as well as from Arab Studies Society (ASs) data for the attributes of the ten blocks, 29 through 38 .

The data in this table examines properties in the post-1967 expanded Jewish Quarter, which includes annexed segments from the Armenian Quarter and the Christian Quarter. The breakdown of ownership of plots addresses the situation as it existed up to 1967 . This data reflects the preponderance of Islamic family waqf plots over all other properties, amounting to 40 percent of the total parcels - a ratio which exceeds its weight in other areas of the Old City. Another observation is the low percentage of parcels that belong to public

TABLE 25.2 Distribution of private and endowed properties in the expanded Jewish Quarter, 2013

\begin{tabular}{lrrrrrrr}
\hline Block No. & $\begin{array}{l}\text { Islamic } \\
\text { family } \\
\text { waqf }\end{array}$ & $\begin{array}{l}\text { Arab } \\
\text { private } \\
\text { property }\end{array}$ & $\begin{array}{l}\text { Jewish } \\
\text { property }\end{array}$ & $\begin{array}{l}\text { Islamic } \\
\text { waqf }\end{array}$ & $\begin{array}{l}\text { Christian } \\
\text { church } \\
\text { waqf }\end{array}$ & Other & Total \\
& 38 & 75 & 10 & - & 3 & 1 & 127 \\
$\mathbf{2 9}$ & 15 & 11 & 1 & - & 5 & 4 & 36 \\
30 & 18 & 7 & 34 & 9 & - & 1 & 69 \\
31 & 21 & 1 & 13 & - & - & - & 35 \\
32 & 41 & 22 & 27 & - & - & - & 90 \\
33 & 43 & 16 & 8 & - & - & - & 67 \\
34 & 7 & 4 & 6 & - & - & - & 17 \\
35 & 20 & 21 & 10 & - & - & - & 51 \\
36 & 18 & 44 & 3 & - & 1 & 1 & 66 \\
37 & 27 & 20 & 1 & - & - & - & 48 \\
38 & 248 & 221 & $\mathbf{1 1 3}$ & 9 & 9 & 6 & 606 \\
Total Parcels & & & & & & & \\
\hline
\end{tabular}

SOURCES: ADNAN 'ABDUL RAZIQ, HARAT AL-YAHUD FI AL-QUDS [THE JEWISH QUARTER IN JERUSAlEM] (NICOSIA: RIMAL PUBLICATIONS, 2013), 127 AND ASS/TAAWON "SURVEy of OLD CITY PROPERTIES" (UNPUBLISHED MANUSCRIPT, 2014). 
(that is, khayrī) Christian and Muslim waqf (amounting to 1.5 percent only for each). Unfortunately, we can only point here to the number of parcels in the ten blocks and not to its area, meaning that we must exercise caution in these projections. The only area that allows for accuracy in assessing the area in question is the Mughrabi Quarter, which is cited further.

As for Jewish properties, the data in table 25.3 indicates that 113 out of 606 parcels, or 19 percent of the total, belong to Jewish owners. The data available does not allow us to distinguish between private properties and Jewish waqf (endowed) properties. The data also reflects the high proportion of private Arab properties, amounting to 36 percent of the total (221 parcels), which is also one of the highest proportions of privately owned properties in the Old City on the whole. ${ }^{40}$ If we use the number of parcels to compare Arab-owned to Jewish-owned properties, we can arrive at a clearer picture for the ethnic breakdown of ownership, as can be seen in table 25.3.

TABLE 25.3 Ratio of Jewish and Arab properties in the expanded Jewish Quarter, 1968

\begin{tabular}{lccl}
\hline Block number & Number of parcels & $\begin{array}{l}\text { Percentage of Jewish } \\
\text { properties in block }\end{array}$ & $\begin{array}{l}\text { Percentage of Arab } \\
\text { properties in block }\end{array}$ \\
\hline 29 & 127 & $7 \cdot 9$ & 92.1 \\
30 & 36 & 2.8 & 97.2 \\
31 & 69 & $49 \cdot 3$ & 50.7 \\
32 & 35 & $37 \cdot 1$ & 63.9 \\
33 & 90 & 30 & 70 \\
34 & 67 & 11.9 & 88.1 \\
35 & 17 & 35 & 64.7 \\
36 & 51 & 19 & 80.4 \\
37 & 66 & 4.6 & 95.4 \\
38 & 48 & 2.1 & 97.9 \\
Total & 606 & $\mathbf{1 8 . 6}$ & $\mathbf{8 1 . 4}$ \\
\hline
\end{tabular}

SOURCES: ADNAN 'ABDUL RAZIQ, HARAT AL-YAHUD FI AL-QUDS [THE JEWISH QUARTER IN JERUSALEM] (Nicosia: Rimal PUblications, 2013) AND ASS/TAAWON, "SURVEy OF OLD CITY PROPERTIES" (UNPUBLISHED MANUSCRIPT, 2014).

40 Adnan 'Abdul Raziq, Harat al-Yahud fi al-Quds [The Jewish Quarter in Jerusalem] (Nicosia: Rimal, 2013), 49, 51. 
Table 25.3 indicates substantial Jewish properties in blocks no. 31 (49.3 percent of total properties in that block), no. 32 (37.1 percent), no. 33 (3o percent), no. 35 ( 35 percent), and no. 36 (19 percent), that is, in five blocks out of ten. As for blocks no. 29, 30, 34, 37, and 38, those properties are negligible.

The data that we have in this survey, as well as in 'Abdul Raziq's study of the Jewish Quarter, do not distinguish between Jewish waqf endowments and Jewish private property. It also assumes that Jewish property owners are non-Arab by definition. This might be a moot point today, but the reader should be reminded that a considerable number of Jewish families from the Old City, especially those that were most likely to have Jewish family endowments, such as the 'Elyashar, Toledano, and Navon families, did not always consider themselves as part of the Zionist settlement project in the Yishuv, and were often self-defined as native, Ottoman, or even Arab Jews. In his study of Jewish and Christian waqf properties in Palestine at the end of the Ottoman era, Ron Shaham notes that many Jews and Christians used to establish family waqf endowments, as well as convert their properties into public charities (waqf khayri) in their communities, in order to protect them from state intrusion. Contrary to common perception, Shaham notes that well-known Jewish families chose to register their properties as waqf $d$ hirri (family endowments) in the Jerusalem and Jaffa shari'a courts. Those included the families of Youssef Nigo and Maymon Amipal. The Jewish religious establishment was divided on the issue of registering Jewish property in Islamic courts, but a majority supported this process, basing their support on the position that the "ruler's law is our law."41

Jewish properties in the ten blocks analyzed here $(10-38)$ amounted to 18.6 percent of the total. The overall size cannot be determined from the existing data, although an approximation can be reached if we assume that the averages are similar to those in Arab areas. ${ }^{42}$ The only area for which we have concrete data on the size of waqf properties in the expanded Jewish Quarter are the estates of the Mughrabi Quarter, which was annexed and

41 Ron Shaham, "Christian and Jewish 'Waqf' in Palestine during the late Ottoman Period," Bulletin of the School of Oriental and African Studies 54, no. 3 (1991). Data for Jewish properties in Jerusalem and Islamic courts can be found in the following entries: Mahkama Shar'iyya, Al Quds, vol. 27, fols. 173-74; Mahkama Shar'iyya, Al Quds, vol. 71, fol. 143; Mahkama Shariyya, Jaffa, vol. 47 , fol. 276.

42 There are noticeable variations in calculating the averages for Jewish properties between tables 25.2 and 25.3 above. However, these variations do not appear significant in calculating the total averages. See 'Abdul Raziq, Harat al-Yahud, 126-27. 
demolished in 1967-68 in order to expand the Western Wall/Buraq Wall Plaza. Since then, these estates have become part of the expanded Jewish Quarter. ${ }^{43}$

The survey undertaken of this area by the Ass indicates that the total number of properties in the Mughrabi Quarter was 127 units, of which 104 were registered as dhirri waqf. Islamic khayri waqf amounted to only 3 percent of the total, while Jewish properties amounted to 2 percent of the total, and the Mughrabi waqf amounted to 10 property units, or 8 percent of the total. The Abu Madyan family owned the single highest aggregate of properties in the area -73 property units, equivalent to 70 percent of all family endowments, followed by the Khalidi family (14 percent) and the Abu Sa'ud family (6 percent).$^{44}$

Table 25.4 attempts to situate the status of various waqf categories (family, public and religious) in the context of all property categories in the city, including private property, to gain a relational perspective. Here we have divided the table into two components, one side referring to data from the Ass survey (excluding blocks 29-38, that is, the post-1967 expanded Jewish Quarter), and the other side containing all blocks in the city, for purposes of comparison.

The significance of table 25.4, comparing the attributes of all categories of property, first without the expanded Jewish Quarter (blocks 29-38), and then with the expanded quarter, is that it shows very few variations in the percentage of parcels. One may conclude that the distribution of endowed properties contains a higher proportion of Jewish-owned properties (18 percent of the total) than any other area in the Old City, as would be expected. It also contains the highest proportion of family endowments (waqfiyyāt) than the average for the rest of the Old City ( 41 percent are Muslim endowments and 15 percent city endowments). The table shows the continued high significance of family waqf over all categories of ownership, the preponderance of church endowments, and the categorical plurality of private property plots in the Old City, despite the continued adoption of family and public waqf as a means of protecting property from state encroachment and confiscation.

43 The Arab Studies Society has provided data on the confiscated and destroyed properties in blocks nos. 33, 34, 35, and 38 in 1967-70. In those four blocks, the total confiscated properties amounted to 56.5 dunums, equivalent to 29 percent of the total area in this zone. See 'Abdul Raziq, Harat al-Yahud, 124.

Ass/WA, "Survey of Old City Properties" (unpublished manuscript, 2014). 
TABLE 25.4 All categories of property in Jerusalem's Old City, including waqf categories, mid-twentieth century

\begin{tabular}{|c|c|c|c|c|}
\hline \multirow[t]{2}{*}{ Category of property } & \multicolumn{2}{|c|}{$\begin{array}{l}\text { Number and percentage of } \\
\text { properties excluding blocs } 29^{-} 3^{8}\end{array}$} & \multicolumn{2}{|c|}{$\begin{array}{l}\text { All city properties, including data } \\
\text { for blocs } 29-38\end{array}$} \\
\hline & $\begin{array}{l}\text { Number of } \\
\text { parcels }\end{array}$ & $\begin{array}{l}\text { Percentage of } \\
\text { total }\end{array}$ & $\begin{array}{l}\text { Number of } \\
\text { parcels }\end{array}$ & $\begin{array}{l}\text { Percentage of } \\
\text { parcels }\end{array}$ \\
\hline State property & 11 & $<1$ & 13 & $<1$ \\
\hline $\begin{array}{l}\text { Jerusalem } \\
\text { municipality }\end{array}$ & 27 & 1 & 30 & $>1$ \\
\hline (Jordanian) & 69 & 2 & 70 & $>2$ \\
\hline $\begin{array}{l}\text { Custodian of } \\
\text { Enemy Property }\end{array}$ & & & & \\
\hline Islamic waqf & 302 & 9 & 311 & 8 \\
\hline Family waqf & $5^{67}$ & 17 & 815 & 21 \\
\hline Church waqf & 912 & 20 & 921 & $23 \cdot 5$ \\
\hline Private property & 1,404 & 42.5 & 1,731 & 44.5 \\
\hline
\end{tabular}

SOURCE: ASS/TAAWON, "SURVEY OF OLD CITY PROPERTIES" (UNPUBLISHED MANUSCRIPT, 2014); ADNAN 'ABDUL RAZIQ, HARAT AL-YAHUD FI AL-QUDS [THE JEWISH QUARTER IN JERUSALEM] (NICOSIA: RIMAL PUBLICATIONS, 2013).

\section{Conclusion}

This study examined the changing status of endowed properties (family and public) on the eve of Israeli occupation of the Old City of Jerusalem and its subsequent annexation in 1968. The main historical source for analyzing waqf properties in Jerusalem and other Arab cities have been hujjaj (deeds) of endowments recorded in the Islamic court records, and the Ottoman tax registry known as Tahrir defterleri. The study referred to the utility of several new archival sources for assessing waqf properties: these include architectural field surveys of private homes and public establishments in the city, aerial photography recently made available from British, Ottoman, German, and Israeli sources, and municipal tax registers of Old City properties and leases. The last mentioned have been in existence for many decades, but was made accessible only recently. 
One main finding of this study is historical continuity in the use of public endowments as a means of providing medical, health, and schooling facilities for the poor. There has been a historical decline in the use of royal (or state) decrees in allocating waqf property as a form of patronage or, as in the case of Hasseki Sultan during the sixteenth century, for the provision of soup kitchens and other facilities for the poor. Those were endowed in the past in order to commemorate the name of the sultan, the royal family, or urban potentates. The state has assumed many of these functions in an increasingly secularized form. By contrast, family waqf deeds, which have been a historical instrument for preserving family property from fragmentation through inheritance, have continued to be used in Palestine, and in particular in the Old City of Jerusalem. Family (dhirri) waqf registration has been a crucial instrument in responding to political crisis in various periods of the twentieth century (World War I, Arab Revolt of 1936, 1948 War, and Israeli occupation and annexation of Jerusalem in 1967).

Another aim of this chapter was to assess the relative weight of endowed properties in relation to landed property in general. The Old City is unique in its preponderance of waqf establishments of all varieties: an astonishing one-fifth (21 percent) of all title deeds belong to family waqf, probably one of the highest in the Islamic and Arab regions. Another surprising finding is the high proportion of church property in the city that is registered as waqf (23 percent vs. 8 percent for Islamic public waqf), though this figure is somewhat exaggerated by the exclusion of the Haram area from the total area of waqf establishments. Although not technically an endowed property, the Haram provides many functions of charitable endowments under the same rubric: schools, libraries, Sufi zāwiyāt and soup kitchens. Finally, although private property deeds make up the majority of registered deeds in the Old City (1,771 parcels or 45 percent of all property deeds), they are nevertheless much lower than the ratio in any comparable city in the Middle East or North Africa. There is little doubt that the enhanced and enhancing role of family endowments has appreciated at the expense of private property.

The main problem with these extrapolations remains the calculation of property sizes (as opposed to the number of parcels and property units in each bloc). This remains unfeasible except in certain neighborhoods and segments of neighborhoods referred to in the body of the chapter (for example, the Mughrabi Quarter). What we have here is a concrete picture of the relative weight of the number of parcels in each property category, but great uncertainty about the area involved. We have assumed that the relative value of property units, on average, corresponds to its surface area, but this assumption needs to be examined more rigorously. This absence is due to limitations 
inherent in the GIS data calculated by the Ass/Taawon survey for this study as well as to our inability to achieve synchrony between the four archival sources utilized here to assess the overlapping categories of property: probate court records (hujjaj of endowments and property deeds), aerial photographic mapping, in situ architectural drawing of Old City buildings, and tax registration records.

Another shortcoming of this study is that it fails to assess the effects of changes brought about by the presence of settlers in the Old City, including land purchases and confiscation of private property, and changes brought about by Israeli government sequestrations of public property. We have discussed this issue briefly but the issue must be examined further. 